УДК 330.837:330.101

DOI: https://doi.org/10.26642/jen-2019-4(90)-67-7

Ю.В. Ущаповський, к.е.н., доц.

Державний університет «Житомирська політехніка

\title{
Імплементація формальних інституцій у дослідженнях Київської економічної школи XIX століття
}

У роботі здійснено ретроспективний аналіз з позицій сучасного інституціоналізму формальних інституцій та інституційного порядку у праиях представників Київської економічної школи ХІХ ст.: Миколи Бунге, Афіногена Антоновича та Дмитра Піхна.

Особливу увагу приділено дослідженню проблеми імплементації новітніх інституиій та ї̈ зв'язку з інтересами суспільства, значенню держави у створенні інституційних обмежень та формуванні інституційного порядку.

Досліджено розуміння економічного порядку М.Бунге у площиині сучасного інституційного аналізу. Проаналізовано вплив вченого на економічну політику Російської імперії на посаді міністра фінансів у контексті проблеми імплементаџії інституції промислової свободи, щяо покликана розкрити творчий потенціал суспільства.

3'ясовано розуміння А.Антоновичем ролі $i$ місия держави у створенні сприятливого інституційного середовища як зовнішнього елемента для економічного розвитку.

Підкреслено розуміння Д.Піхном проблеми глибини державного втручання в господарське життя та погляд на економічні закони як на своєрідний обмежуючий фактор такого втручання.

Автор приходить до висновку, щзо представники Київської економічної школи досліджували інституиійний порядок у контексті економічної діяльності держави. Зокрема, М.Бунге підкреслював важливість інституційних обмежень та формування інституційного порядку у контексті поєднання індивідуальних та суспільних інтересів; А.Антонович проблему імплементації інституиій ставив у безпосередню залежність від усвідомлення народом своєї свободи, його інтелектуального та морального розвитку; Д.Піхно розумів економічні закони як своєрідний обмежуючий фактор глибини втручання держави в економічні процеси.

Ключові слова: формальні інституцій; інституціоналізм; інституційний порядок; імплементація інституційі; методологія інституціоналізму; інституційна структура економіки.

Актуальність теми. Феномен Київської економічної школи у 70-ті роки XIX ст. пов'язаний, 3 одного боку, з пожвавленням економічних досліджень, пов'язаних з реформою господарства у Російській імперії після відміни кріпосного права, а з другого боку - з кризою класичної політичної економії. Через зрозумілі обставини наукові досягнення Київської економічної школи не були належним чином реалізовані в українській економічній науці, а тому вони потребують критичного переосмислення i врахування у сучасних економічних реаліях.

Аналіз останніх досліджень та публікації. Інституційним складовим економічних досліджень Київської економічної школи ХІХ ст. приділяли увагу такі відомі українські вчені, як С.Злупко, Л.Корнійчук, П.Леоненко, Т.Гайдай, А.Маслов, В.Небрат, Н.Супрун, В.Фещенко, О.Шевченко та ін. Слід підкреслити вагомість досліджень українських вчених у дослідженні інституційних аспектів української економічної спадщини. Значна література із згаданої проблематики все ж залишає поле для ретроспективного аналізу висвітлення інституційного порядку у працях представників Київської економічної школи 70-90-х рр. ХІХ ст.

Метою статті є ретроспективний аналіз 3 позицій сучасного інституціоналізму формальних інституцій та інституційного порядку у працях представників Київської економічної школи XIX ст.: Миколи Бунге, Афіногена Антоновича та Дмитра Піхна.

Викладення основного матеріалу. Найкраще розуміння Миколою Бунге держави та юридичних форм реалізації економічних відносин (формальних інституцій) розкриваються у площині еволюції поглядів вченого щодо взаємозв'язку між економічною теорією і економічною практикою. Це особливо цікаво, оскільки на долю М.Бунге випала унікальна можливість на державному рівні втілити свої теоретичні переконання в економічну практику.

У процесі реалізації вченим державної економічної політики його теоретичні переконання значно трансформувалися: від ідей лібералізму за зразком Адама Сміта до протекціонізму німецької історичної школи. На це звертали увагу такі українські дослідники, як В.Базилевич, Т.Гайдай, Л.Горкіна, С.Злупко, Л.Корнійчук, І.-С. Коропецький, П.Леоненко та інші. У констатації цього факту нічого нового немає. Проте у контексті інституційного аналізу викликає зацікавлення: як розумів М.Бунге інституційний 
порядок у магістерській праці «Дослідження витоків торгового законодавства Петра Великого» (1847)? Він зауважує, що в запереченні втручання уряду фізіократи та прихильники А.Сміта «зайшли надто далеко», оскільки у них «ідея держави як економічного цілого майже зникає». На його думку, держава як цілісність «не прийме економічного порядку, що спирається на прозоро-космополітичний принцип», а тому слід «знешкоджувати вороже зіткнення егоїстичних інтересів та скеровувати їх для досягнення загального добробуту» [2, с. 3 ] (курсив наш - Ю.У.). Показово, що у цій ранній праці М.Бунге пропонує об'єднати дві попередні економічні системи поглядів: «надати найбільшої свободи прояву приватних господарських інтересів, тісно зв'язати їх між собою і з інтересами держави, у якій повинна полягати для них можлива гарантія» [2, с. 4].

Отже, у магістерському дослідженні вчений прагнув об'єднати концепцію «держави добробуту» камералістики 3 концепцією «laisser faire» класичної політичної економії. Сприяння держави, на його думку, необхідне, щоб: 1) подолати перешкоди, які зустрічає розвиток промисловості у народі; 2) забезпечити промислову діяльність; 3) сформувати такі господарські взаємини між народом і владою, які б сприяли «успіхам життя суспільного». В даному випадку інтереси держави М.Бунге ставить вище за приватні інтереси, реалізувати які можливо тільки у площині досягнення інтересів суспільних, які у нього ототожнюються переважно з інтересами держави: «Коли справа стосується існування держави як самостійної цілісності, інтереси держави нерідко беруть верх над промисловими» [2, с. 4].

Але вже у докторській дисертації «Теорія кредиту» (1852) у вченого простежується зміщення акцентів у ставленні до держави в бік концепції «laisser faire». Особливе місце він приділяв кредиту як інституції, що має вирішальний вплив на розподіл продуктивних сил, зростання капіталів та збільшення доходів. Кредит у М.Бунге є наслідком еволюції виробництва та обміну і, передусім, є сферою приватнокапіталістичних відносин, а прагнення залишити кредитний обіг у руках держави вчений вважав помилковими. Такий підхід був продиктований розумінням значення комериіийого кредиту в трансформації господарських відносин, забезпеченні динамічного розвитку виробництва та обміну, модернізації грошового обігу.

Сучасна українська дослідниця В.Небрат зазначає, що у М.Бунге морально-правовими (інституційними) основами кредиту є «традиції, звички, довіра та юридично закріплені зобов'язання» [5, с. 49]. Однією із суттєвих ознак кредиту вчений називає неформальну інституцію довіри. Проте він застерігає: «Ми не можемо допустити, щоб довіра була чисто моральним елементом, що не передбачає жодної господарської гарантії: ні продуктивності праці, ні наявності майна. Інакше чи могла б існувати довіра до майбутньої винагороди?» [4, с. 290]. Таким чином, завдяки встановленню правових норм довіра формалізується як інституція кредиту.

Розуміння значення формальних інституцій у теоретичній концепції М.Бунге добре розкриває його доповідь «Про місце, щзо займає політична економія...» (1856). Він вважає, що «призначення закону — встановлення норм для суспільних відносин загалом, так і для економічних зокрема, та охорона їх поліційними та судовими заходами» [3, с. 666]. Вчений надзвичайно чітко розмежовує неформальні та формальні інституції (звісно не вживаючи таких термінів): «Коли б закон встановлював тільки те, що вироблене звичаями та внутрішнім життям суспільства, то навіть тоді розуміння його вимагало б політико-економічних знань: тим більше це необхідно, коли він стає знаряддям перетворень, коли знищуючи обмеження, що зустрічаються у приватній діяльності, він прискорює господарський розвиток суспільства, коли, скасовуючи застарілі форми, що тяжко підтримують існування віджилого, він спонукає до самодіяльності і народної творчості в перевтіленні господарського порядку» [3, с. 666]. Таким чином, М.Бунге поставив проблему ролі і місця формальних інституцій права в процесі реформування суспільства, і, висловлюючись сучасною термінологією, проблему імплементації новітніх інституцій. Як видно, вчений застерігав щодо необхідності формалізації у нормах права усіх неформальних інституцій, оскільки деякі 3 них можуть бути стримуючими факторами на шляху суспільного прогресу.

3 певними застереженнями економічний порядок можна розглядати як наслідок і результат інституційного порядку, а отже, в контексті нашого дослідження розуміння вченим інституції «порядку» викликає зацікавлення. У ставленні до економічного порядку М.Бунге виокремлював два підходи:

1) економічний порядок - штучний витвір діяльності людини та органів суспільної влади, а тому економічна наука розглядається ним як «набір рецептів для поширення суспільного добробуту»;

2) економічний порядок - природний порядок, який «створений не свавіллям, а природною необхідністю, і коріння його міститься у природі людини суспільної».

Перший підхід не визнає дії природних економічних законів, а тому не надає їм суттєвого значення в господарській практиці. В разі визнання істинним першого підходу вчений рекомендує широко залучати досягнення політичної економії. Натомість, визнавши істинним другий підхід, слід обмежити претензійність щодо нав'язування суспільного добробуту, а зосередитися на покращенні освіти та переконанні суспільства: «ми повинні взяти за точку відліку суспільство, з його побудовою та його поняттями» [3, с. 675-676]. 
На наш погляд, М.Бунге у ранній науковій творчості мав усі підстави зараховувати себе до прибічників концепції «laisser faire». Свою прихильність до концепції природного порядку вчений пояснював зростанням ролі економічної науки у дослідженні господарських законів. Він особливо підкреслював: «не юридичних, а природних» законів.

Усвідомлюючи необхідність впровадження системи «laisser fair», вчений розуміє складність такого завдання та застерігає від помилкового іiі розуміння, як ідеї «нічого не робити». На противагу організаторам-протекціоністам М.Бунге вважає, що метою уряду є реалізація промислової свободи як засобу активізації творчих сил суспільства, а не роль «досвідченого механіка» у керуванні народним господарством для спільного блага. На його думку, підвищення добробуту - це добра мета, але відсутність свободи в економічному середовищі може звести нанівець усі добрі наміри.

Микола Бунге очолив фінансове управління у 1881 році, коли у Росії домінували ідеї «ізоляціонізму» в економічному житті, - уряд прагнув протидіяти вторгненню іноземного капіталу та робочої сили у фабричну промисловість. Державне господарство ще не зовсім одужало від наслідків турецької війни, фінанси перебували у вкрай розбалансованому і занедбаному стані, майже зовсім непридатною була система оподаткування. Життя вимагало систематичної і послідовної фінансової політики.

Бунге М. прагнув покращити економічний добробут населення, в першу чергу, селянського. Щоб розчистити шлях для економічного прогресу і створити для нього сприятливі умови, було проведено низку заходів, які сприяли кінцевому викупу державними селянами їхніх земель: відмінено подушний податок, здійснено реформу земельного оподаткування, засновано селянський земельний і дворянський банки. Протекціоністські заходи, яких вимагали від М.Бунге, вступали в суперечність з його власними переконаннями. Очевидно саме тому він спочатку відхиляв проекти перегляду усього митного тарифу в бік протекціонізму на тій підставі, що такі докорінні перетворення нерідко мають несприятливі наслідки.

Отже, на початку наукової діяльності М.Бунге були притаманні ліберальні погляди. Це видно у його визначенні співвідношення між приватною ініціативою і політикою держави. Еволюція в сторону протекціонізму у його творчості простежується з 60-х рр. XIX ст., проте ії основи були закладені ще в ранніх працях вченого. Розвиток поглядів науковця на економічну політику відбувався разом зі зміною його теоретичних підходів до економічних явищ, які він неодмінно коригував стосовно соціальноекономічних процесів у Російській імперії. Зокрема, до протекціонізму М.Бунге підштовхнуло розуміння зростаючої ролі держави у реформуванні господарського життя, особливо успіхи реформи 1861 р. Навіть протягом праці на урядових посадах вченого не можна вважати доконаним протекціоністом: до економічних конструкцій протекціоністів він ставився напрочуд зважено. Державу він розглядав як засіб, який допоможе Російській імперії позбутися середньовічних господарських відносин і послідовно впровадити механізм вільного ринку без надмірної опіки з боку урядових структур. Свобода господарської діяльності і приватне підприємництво повинні доповнюватися прагматичною регуляторною політикою держави 3 метою вдосконалення ринкового механізму ціноутворення та оподаткування. Це й була та «золота середина», до якої прагнув у своїх поглядах Микола Бунге впродовж свого життя.

Афіноген Антонович також вважав, що господарське життя має підпорядковуватися дії природних економічних законів, а допомогти у їх 3'ясуванні має політична економія: «Визнаючи у сфері суспільних явищ існування природних законів, ця наука одночасно висловлює думку, що вивчивши ці закони, ми можемо керувати ними відповідно до наших цілей» [1, с. 19-20]. На думку А.Антоновича, не пізнавши природних законів, економіст бере на себе роль «організатора», який свавільно використовує правила та рецепти в розробці проектів «загального щастя». Економічні закони позбавлені фаталізму фізичних законів, оскільки в них закладена здатність до розвитку. Розвиток А.Антонович розглядав як поступову реалізацію можливостей, які приховані у самому зародку предмета розвитку. На цей процес, крім внутрішніх елементів, також суттєво впливає середовище як елемент зовнішній. Такі висловлювання дають нам всі підстави розглядати вченого серед прихильників концепції «laisser faire». Проте А.Антонович проявив вірність «еклектичним традиціям» Київської економічної школи у «Курсі державного благоустрою (поліцейського права)»

Розширення поліційних функцій держави А.Антонович аргументує певними причинами, зокрема, неосвіченістю громадян, яка може бути стримуючим фактором розвитку. На його думку, держава не може очікувати того часу, коли народ сам почне дбати про свій розумовий розвиток, бо йому може загрожувати небезпека політичного і економічного поневолення. Таким чином, подібно до М.Бунге, проблему імплементації інституизій вчений ставить у залежність від інтересів суспільства та його безпеки, а межі втручання держави у приватне життя та діяльність громадян — від конкретних обставин: усвідомлення народом своєї свободи, його інтелектуального та морального розвитку.

Вивчати «умови найдоцільнішого впливу держави на народне господарство», на думку вченого, має особлива наука - юридична економія або поліцейське право. Завдання поліцейського права полягає у «вивченні серед різноманітності відносин життя господарських норм» 3 метою: 
1) упередження дій, що порушують наявний добробут;

2) сприяння подальшому розвитку «народного блага».

Антонович А. підкреслює, що юридична економія «вивчає правові підстави, за допомогою яких закони політичної економії знаходять потрібне використання і досягається встановлення народного добробуту» [1, с. 85-86] (курсив наш - Ю. У.).

Окреме місце у своєму дослідженні А.Антонович відводить кредиту та його зв'язку з державною економічною політикою. Вчений коротко досліджує еволюцію державної економічної політики в галузі кредиту протягом останніх століть. Він вважає, що незважаючи на приватний характер, кредит має суспільне значення через його тісні зв'язки із суспільним господарством, а тому потребує особливої регламентації.

Погляди Дмитра Піхна щодо ролі держави у формуванні інституційної структури економіки найвиразніше репрезентовані у його статті «Про свободу міжнародної торгівлі і протекціонізм» (1889). Проблему меж та рівня втручання держави в економічну діяльність він вважав однією із складних в економічній теорії і практиці. На його думку, вирішення цієї проблеми ускладнене різними підходами щодо завдань держави та тісним зв'язком між інтересами приватними та суспільними.

Піхно Д. чітко розмежовував два традиційні підходи до цієї проблеми: політику «laissez faire» та протекціонізм. Перший підхід сконцентрований на забезпеченні державою юридичного підгрунтя для вільної економічної діяльності та безпеки громадян. Натомість другий підхід, крім згаданих «негативних» функцій, передбачає сприяння 3 боку держави поширенню економічної діяльності «різноманітними позитивними» заходами в контексті досягнення суспільного блага. На думку Д.Піхна, критерієм, що розмежовує два підходи, є надання пріоритету в економічної діяльності: в першому випадку - приватному підприємництву; у другому випадку - державі.

Досліджуючи історичну еволюцію зв'язків між окремими господарськими одиницями і державою, Дмитро Піхно підкреслює значення суспільного поділу праці, діяльності «суспільно-господарських установ», кредиту у формуванні цілісної господарської системи суспільства. Вчений надає переваги економічній політиці, яка б враховувала закладений у народному господарстві тісний взаємозв'язок між приватними і суспільними інтересами: «Потрібно віднайти таке співвідношення між ними, яке найкраше забезпечило б по-можливості повний простір приватної діяльності, найкраще сприяло б їі успіхам i, водночас, захищало б інтереси суспільства» [6, с. 3].

Піхно Д. поставив проблему глибини державного втручання в господарське життя: «Спадковість i органічний характер народного господарства надзвичайно ускладнюють завдання держави, а тому питання може бути не про те, чи доцільне втручання держави в господарську діяльність, а про доцільні межі такого втручання» [6, с. 4]. Вирішення згаданої проблеми, на думку вченого, не може мати універсального характеру, а має враховувати конкретно історичні обставини та сфери господарської діяльності.

У другій половині ХІХ ст. у Російській імперії прискореними темпами розвивалися залізничний транспорт і перевезення, що вимагало особливої тарифної політики держави у цій сфері. Дмитро Піхно приділив зазначеній проблемі окрему працю «Залізничні тарифи. Досвід дослідження иін залізничного перевезення» (1888). Книга має особливу цінність, оскільки написана вченим на основі власного досвіду перебування у 1885-1888 pр. на посаді чиновника з особливих доручень міністерства фінансів.

Ефективно керувати мережею залізниць, на думку Д.Піхна, може тільки держава. Проте він застерігає від «економічного абсолютизму» такої важливої для народного господарства сфери, якою є залізничні перевезення. Держава на основі натурального або історичного підходів має запровадити

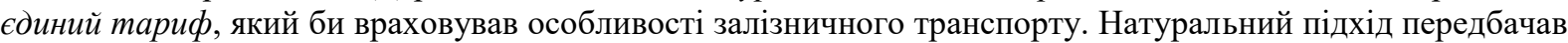
порівняння витрат перевезень вантажів для різних умов. Вчений надавав перевагу історичному підходу, в основі якого платоспроможність вантажів, диференційована залежно від цінності вантажу та відстані транспортування. За допомогою єдиного тарифу вчений прагнув впливати на експлуатаційні витрати залізниць і рухомого складу. Не виключав він також регіональних відмінностей єдиного тарифу, оскільки розумів складності його впровадження.

Таким чином, у Дмитра Піхна розуміння ролі і місця держави у формуванні економічного порядку суттєво не відрізняється від іiі розуміння іншими представниками Київської економічної школи. Не викликає сумнівів також прихильність вченого до концепції «laissez faire». Економічна політика для Д.Піхна $є$ сферою нормативної економічної теорії, а тому встановлення державою формальних інституцій він підпорядковує дії природних економічних законів. Економічні закони можна розглядати як своєрідний обмежуючий фактор глибини втручання держави в економічні процеси. Проте вчений прагнув враховувати конкретні історичні обставини господарського розвитку Російської імперії, а тому до розробки формальних обмежень господарської діяльності підходив творчо й осмислено.

Висновки та перспективи подальших досліджень. Представники Київської економічної школи розглядали інституційний порядок у контексті економічної діяльності держави. Бунге М. розглядав державу як засіб забезпечення «народного добробуту», а «золотою серединою», до якої він прагнув, були 
свобода господарської діяльності і приватне підприємництво, які мають доповнюватися прагматичною регуляторною політикою держави 3 метою вдосконалення ринкового механізму ціноутворення та оподаткування. Вчений підкреслював важливість проблеми імплементації новітніх інституцій та їі зв'язок з інтересами суспільства, оскільки розумів значення держави у створенні інституційних обмежень та формуванні інституційного порядку.

Антонович А. вважав, що держава не може стояти осторонь забезпечення «народного добробуту» $\mathrm{i}$ обмежуватися тільки гарантуванням безпеки. Заради «спільного блага» держава має покласти на себе поліційні функції. Він проблему імплементації інституцій ставив у безпосередню залежність від інтересів та розвитку суспільства: від усвідомлення народом своєї свободи, його інтелектуального та морального розвитку.

Економічна політика для Д.Піхна є сферою нормативної економічної теорії, а тому встановлення державою формальних інституцій він підпорядковував дії природних економічних законів. Вчений розглядав економічні закони як своєрідний обмежуючий фактор глибини втручання держави в економічні процеси.

\section{Список використаної літератури:}

1. Антонович А.Я. Курс политической экономии: лекции, читанные в университете св. Владимира (оттиск из «Университетских известий» 1886 г.) / А.Я. Антонович. - Киев, 1886. - 654 с.

2. Бунге Н. Исследование начал торгового законодательства Петра Великого / Н.Бунге // Отечественные записки. - 1850. - Т. І. - Кн. XVIII. - Отд. II. - 30 с.

3. Бунге $H$. О месте, занимаемом политической экономией в системе народного образования, и об отношении ее к практической деятельности / М.Бунге // М.Бунге: сучасний дискурс ; за ред. В.Д. Базилевича. - К. : Знання, 2005. - С. 639-691.

4. Бунге Н. Теория кредита / М.Бунге // М.Бунге: сучасний дискурс ; за ред. В.Д. Базилевича. - К. : Знання, 2005. - C. 267-474.

5. Небрат В. Українська фінансова думка другої половини XIX - початку XX століть / В.Небрат. - К. : I-нт екон. та прогнозув., 2007. - 224 с.

6. Пихно Д. О свободе международной торговли и протекционизме / Д.Пихно // Университетские известия. Киев, 1889. - № 3. - С. 1-26.

\section{References:}

1. Antonovich, A.Ya. (1886), Kurs politicheskoi ekonomii: lektsii, chitannye v universitete sv. Vladimira (ottisk iz "Universitetskikh izvestii» 1886 g., Kiev, 654 p.

2. Bunge, N. (1850), «Issledovanie nachal torgovogo zakonodatel'stva Petra Velikog», Otechestvennye zapiski, Vol. I, Book XVIII, Part II, $30 \mathrm{p}$

3. Bunge, N. (2005), «O meste, zanimaemom politicheskoi ekonomiei v sisteme narodnogo obrazovaniya, i ob otnoshenii ee k prakticheskoi deyatel'nosti», M.Bunge: suchasnii diskurs, in Bazilevich, V.D. ed., Znannya, K., pp. 639-691.

4. Bunge, N. (2005), «Teoriya kredita», M.Bunge: suchasnii diskurs, in Bazilevich, V.D. ed., Znannya, K., pp. $267-474$.

5. Nebrat, V (2007), Ukrai'ns'ka finansova dumka drugoi' polovyny HIH - pochatku HH stolit', K., I-nt ekon. ta prognozuv, $224 \mathrm{p}$.

6. Pikhno, D. (1889), «O svobode mezhdunarodnoi torgovli i protektsionizme», Universitetskie izvestiya, Kiev, No. 3, pp. 1-26.

Ущаповський Юрій Володимирович - кандидат економічних наук, доцент Державного університету «Житомирська політехніка».

Наукові інтереси:

- методологічні аспекти інституційного аналізу економічних систем;

- проблеми історії та теорії економічної думки України.

E-mail: ushch@i.ua. 